\title{
Transference of Information in Space and Time. Communication and Transference as a New Type of Dichotomy
}

\author{
Sergei G. Proskurin ${ }^{\mathrm{a}, \mathrm{b}}$ and Anna V. Proskurina ${ }^{\mathrm{b} *}$ \\ ${ }^{a}$ Novosibirsk State University \\ 2 Pirogov Str., Novosibirsk, 630090, Russia \\ ${ }^{b}$ Novosibirsk State Technical University \\ 20 Marx, Novosibirsk, 630073, Russia
}

Received 19.08.2015, received in revised form 21.10.2015, accepted 29.11.2015

The current article deals with the dichotomy communication - transference with respect to the earlier opened dichotomy synchrony-diachrony. The new type of transference is discussed. It is based on the role of performatives as messages which cannot be denied by logics. "Communication" and "transference" play a significant role in preserving non-genetic data. The transference is considered to be a cognitive process, which is aimed at storing information in generations.

Keywords: dichotomy, synchrony, diachrony, transference, communication.

This research was supported by a grant from the Russian Scientific Foundation, Project № 14-28-00130.

DOI: 10.17516/1997-1370-2015-8-12-2934-2938.

Research area: philology.

There is a burning issue about availability of dichotomy communication - transference in addition to the earlier opened dichotomy synchrony-diachrony which was suggested in the course of Ferdinand de Saussure. Any language is characterized as a means of communication, which helps interlocutors to come to mutual understanding. The languages are also characterized by the function of transference of information in generations. The transference embodies some basic identity, common to all the people, who use the native language that allows their offspring to feel at one with the ancestors, consolidating the collective memory of this historic group. To the concept of communication we refer the transmission of information in space within the limits of the same spatial-time sphere, to the concept of transference we refer all that is related to the dynamics of collective memory (transference of information in time).

The communication possesses definite sociological horizons, the interspecies phycology plays a role of a spring board. The transference possesses historic horizon, its springboard

(c) Siberian Federal University. All rights reserved

* Corresponding author E-mail address: s.proskurin@mail.ru, a.vyacheslavovna@gmail.com 
is a technical device with the use of material carrier. The communication is a predecessor of transference, since before the task to carry out the transference of information in space and time there is a need to carry out the communication. Thus the Christian church could never be able to ensure the transference from generation to generation of evangelical message, if Christ does not communicate with the followers. It should be noted that the transition from the communication to the transference means the change of chronological scale, since the transition of message taken at a longer interval brings about transformations. The means of transference of info can be transformed by that substance which was transferred. Since the language is such a means, it serves as an interior vector of the doctrine. However such a vector cannot be external for the message, which is transferred, because the vector is interior. The Christian message was well developed and structured in cultural media, through which this cultural message was transferred and what was transferred by itself (Debre, 2010).

Thus the communication presents itself a transmission of information within the single spatial temporal sphere that is a turnover of message in the given moment of the time. For example a message to the deputy which was posted in the social network, enables him to give a response on behalf of himself or the subordinates. If one describes the communication from the point of view of time scale, it presents itself a synchrony (simultaneous questions and answers), topicality (the addressee who addresses the receiver builds up a message on the basis of topical events), velocity (which is defined by the belonging to the same spatial time sphere of the epoch (Belkina, 2012 (a)). The transference is a transition of information between various spatial temporal spheres. The transference is related to the collective memory.
The transference is carried out in diachronic historical horizon with the imprint in eternity. Because without the material implementation there is no embodiment, the aims of transference are targeted not at the language but the scripture of thought (Belkina, 2012 (b)).

The communication in its nature is always possible whether it is propaganda of political programs or communication with the representatives of mass media. What about transference, the people intentionally transfer and immortalize the most precious, thus projecting themselves into the future. By means of the culture the communication is implemented. It happens through a complex interconnection of cultural events. The communication is a specific operation, which characterizes the social systems. The communication does not transmit the information, but redistribute the knowledge and ignorance (Debre, 2010).

Performatives are directed at the transference of information in space within the limits of the single spatial temporal sphere. Therefore the performatives correspond to the situation, which they create as an action. Otherwise the performatives combine speaking and action. The noun performative originates from the verb perform in combination with the concept action. The performative indicates that the utterance marks the completion of the action, and it does not seem that there is a simple pronouncement of words. It is noteworthy that in the basis of Judeo-Christian belief there lies the speech act of biblical creation. "Originally J. Austin, who contributed to the concept of performative, considered as follows: the performatives are the statements which look like assertions and which can be grammatically classified as assertions and which cannot be senseless and they are neither true nor false. The subjects of the described content are the affirmative statements which contain the 
common verbs in the present tense of the first person, singular in indicative mood.

From the first look it becomes evident that they can be neither true nor false. Moreover, if somebody articulates such utterances it means that he not only speaks but does something. For example, during a wedding ceremony I say I do confirming that I marry this woman or if I stumble upon somebody's foot you say I am sorry, or I keep a bottle of champagne saying that I name this ship The Queen Elisabeth. Thus, the type of utterances, which are considered to be performatives grew in number. In this connection the special emphasis should be given to the utterances which shed light upon how human beings saw the origin of the world (Debre, 2010; Mermaud, 2003).

"A topical network of language and culture is established around the speaker. The language and culture are characterized by the network, which includes performative statements. They are comprehended as data of world history and they cannot be denied. The speech act lies in the basis of the origin of the world. This fundamental speech act is judged as successful and it is not under the influence of Logic. The statements which speak of the origin of the world in mythology and epic literature cannot be judged as true or false. The speech performatives from the third person (One said, or, One uttered etc.) are not typical representatives of performatives in the modern times.

\section{Genesis Chapter 1}

1. In the beginning God created the heaven and the earth.

2. And the earth was without form, and void; and darkness was upon the face of the deep. And the Spirit of God moved upon the face of the waters.

3. And God said, Let there be light: and there was light.
4. And God saw the light, that it was good: and God divided the light from the darkness

5. And God called the light Day and the darkness he called Night. And the evening and the morning were the first day" (Proskurin, 2012:127) (See also Proskurin, 2010).

The demand in the exchange of information is typical of human being. For its history the humans tried many means of preserving oral and written data about life, culture and everything they wanted to transfer their offspring. The communication is transference of info within the same spatial-temporal sphere, which allows interlocutors to come to mutual understanding. It possesses the defenite sociological horizon because interindividual psychology is a launching pad.

Transference is a transition of info between different spatial, temporal spheres. Its launching pad - is a technical implementation with the use of material carrier, because it possesses historic horizon. There is a need to say that communication is a predecessor of transference, because before implementation of transference there is a necessity to carry out a communication. The dichotomy communication/ transference as well as the dichotomy synchronic/diachronic are directly connected, because diachronic layer/transference is based on synchronic layer/ communication.

Thus the communication is transference of information within the same spatial, temporal sphere i.e. circulation of messages at the definite period of time, for example, the message to a deputy placed on the World Wide Web. It eases the response of the deputy and his/her subordinates. If we describe the communication from the point of the scale of time it presents itself a synchronous layer (simultaneous question and answer), topicality (an addresser sends a message to an addressee on the bases of the topical events) and velocity. An addresser 
and addressee are at the same spatial temporal sphere. Transference is a transfer of info between varies spatial temporal spheres. Otherwise transference is a message which is related to the dynamics of the collective memory. The transference presents itself the diachronic layer (historic horizon), imprint (with the use of material carrier the connection between an addresser and an addressee is implemented) and eternity (thanks to historical horizon of transference directed at accumulation) (see Proskurin, Proskurina 2014).

The idea of transference of info is reflected in ancient Germanic poetic tradition, i.e. in the genre of thula. The structure of thula is based on the idea of cycle, which is defined by longevity of a human life. The cycle is equal to epoch or Verold/ weorolde. The word Verold/ weorolde (word to word translationman+time) contains two connected semantic domains "ifespan" and big space cycle (Human age). The content of the thula is enumeration of names in genealogical sequience. The structure of thula is built upon the line $\mathrm{A}+\mathrm{B}+\mathrm{C}$, the story marks the beginning of thula and traced back to the God Wodin:

«Cynric Cerdecing, Cerdic Elesing,

Elesa Esling, Elsa Gewising,

Gewis Wiging, Wig Freawing,

Freawine Fridugaring, Fridugar Bronding,

Brond Baeldaeging, Baeldaeg Wodening» (see Proskurin 1990 ).
Information about life of society was stored in such pieces of poetry and was transferred from a generation to a generation. These thulas were related to names of Old Germanic supreme God as the line of totem - ethnonym. There were definite laws of transferring information in syntagmaticity and paradigmaticity of thulas.

R. Debre (see Debre 2010) as Y.Stepanov (see Stepanov 1975) notices that the concept of "communication" (synchrony) is inalienable from the concept of "transference" (diachrony). Consequently, "communication" is characterized by topicality; "transference" is characterized by eternity. "Communication" and "transference" present some registers, which should be coordinated, not compared. "Communication" (synchrony) and "transference" (diachrony) depend on one another, because "transference" (diachrony) stems from "communication" (synchrony). Thanks to writing system transferring of information became possible and was entrenched in space and time. So, historically the memory of Old Germanic tribes existed in oral form. Writing brought about a global transition from the oral word to the written one during the acquisition of Christianity. Communicative messages became connected with the development of syntagms and transference is based on paradigmaticity which is typical of traditional cultures.

\section{References}

Belkina, A.V. Peredacha I kommunikatsiya $\mathrm{v}$ istoricheskoi lingvistike. Nauka. Tekhnologii. Innovatsii. Materialy vserossiiskoi nauchnoi konferentsii molodych uchyonykch. Novosibirsk, NSTU, 2012(a).

Belkina, A.V. Perenos informatsii v predelakch odnoi ili neskolkikch epokch. Yazyk I Kultura: sbornik materialov 1 Mezhdunarodnoi nauchno-prakticheskoi konferentsii, posvyashchyonnoi pamyati akademika RAS, doktora filologicheskikch nauk, professor Y.S. Stepanova, 18 May 2012. Novosibirsk, NSTU, 2012(b). Part 1, p. 17-24.

Debre, R. Vvedeniye v mediologiyu. Moscow, 2010.

Mermoud, M. La parole magique.Ėtude sur la performativité. Lausanne, 2003. 
Proskurin, S.G. Drevneangliiskaya prostranstvennaya leksika kontseptualizirovannykch oblastei. Diss. ...kand. filol.nauk. Moscow, 1990. 216 p.

Proskurin, S.G. (2010). The role of matrices in preserving non-genetic data Semiotica, 182, 397-408.

Proskurin, S.G. To the question of a topical network of language and culture. Semiotics 2012: semiotics and the new media: proc. of the 37 annu. meet., Ottawa,Canada, 1-4 Nov. 2012. Ottawa, Legas, 2013, p. 125-132.

Proskurin, S.G., Proskurina, A.V. (2014). The communicative extention of a formula. European Social Science Journal, 8-1(47), 252-257.

Stepanov, Y.S. Osnovy obshchego yazykoznaniya. Moscow, 1975.

\title{
Передача информации во времени \\ и пространстве. «Коммуникация и передача» как новый тип дихотомии
}

\author{
С.Г. Проскурин ${ }^{\mathrm{a}, \tilde{\sigma}}$, А.В. Проскурина ${ }^{\sigma}$ \\ ${ }^{a}$ Новосибирский государственный университет \\ Россия, 630090, Новосибирск, ул. Пирогова, 2 \\ ${ }^{6}$ Новосибирский государственный технический университет \\ Россия, 630073, Новосибирск, пр. К. Маркса, 20
}

Настоящая статья имеет отношение к дихотомии «коммуникаџия/передача» по отнотению к раннее открытой дихотомии «синхрония/диахрония». Обсуждается новый тип передачи, он основан на роли перформативов как посланий, которые нельзя отрицать с позиции логики. «Коммуникачия/передача» играют значительную роль в сохранении негенетической информации. «Передача» рассматривается как когнитивный процесс, который направлен на хранение информачии в поколениях.

Ключевые слова: дихотомия, синхрония, диахрония, коммуникачия, передача.

Исследование было поддержано грантом Российского научного фонда, проект № 14-28-00130. Научная специальность: 10.00.00 - филологические науки. 